\title{
Formulation and Penetration Enhancement Activity of Sticks Containing Caffeine
}

\author{
Raditya Iswandana', Whinanda Chalista', Eme Stepani Sitepu \\ 'Laboratory of Pharmaceutical Formulation and Development, Faculty of Pharmacy, Universitas Indonesia, Depok, 16424, Indonesia. \\ 'Laboratory of Pharmaceutical-Medicinal Chemistry and Bioanalysis, Faculty of Pharmacy, Universitas Indonesia, Depok, 16424, Indonesia.
}

\section{ARTICLE INFO \\ Article history: \\ Received on: 18/11/2017 \\ Accepted on: 26/12/2017 \\ Available online: 28/01//2018}

\section{Key words:}

Caffeine, emulsion, micro-

emulsion, penetration, stick.

\begin{abstract}
Caffeine is a methylxanthine alkaloid that has been widely used in cosmetic products as anti-cellulite. Caffeine has a hydrophilic character. Thus it has difficulty in penetrating the lipid layer of the skin. This study aimed to formulate sticks containing emulsion and microemulsion caffeine (control stick), caffeine emulsions (emulsion stick), and caffeine microemulsion (microemulsion stick) and compare the penetration between them. Caffeine was made in the form of water in oil emulsions and microemulsion then form into sticks-shaped with the lipophilic component. All sticks were physically and chemically evaluated. The penetration of caffeine through Sprague-Dawley rat skin using Franz Diffusion Cell were tested for 12 hours. The penetration result of caffeine from control stick, emulsion stick, and microemulsion stick were $306.42 \pm 34.92 \mu \mathrm{g} / \mathrm{cm}^{2}, 927.75 \pm 57.38 \mu \mathrm{g} / \mathrm{cm}^{2}$, and $2408.68 \pm 81.65 \mu \mathrm{g} / \mathrm{cm}^{2}$ respectively, with percentage $5.90 \pm 0.67 \%, 12.76 \pm 0.78 \%$, and $35.23 \pm 1.19 \%$. Physical and chemical stability tests were performed for eight weeks at room temperature $\left(29 \pm 2^{\circ} \mathrm{C}\right)$, cold temperature $\left(4 \pm 2^{\circ} \mathrm{C}\right)$, and hot temperature $\left(40 \pm 2^{\circ} \mathrm{C}\right)$. Microemulsion stick delivered the highest cumulative amount of caffeine in penetration test for 12 hours, followed by emulsion stick and control stick. Also, all sticks showed physical and chemical relatively stable.
\end{abstract}

\section{INTRODUCTION}

Caffeine is a methylxanthine alkaloid which commonly consumed as a beverage, administered as a drug, and applied as cosmetic. Caffeine has been clinically proven as anti-cellulite (Luo and Lane, 2015). Caffeine acts directly on adipose cells by stimulating the lipolysis process and inhibiting phosphodiesterase enzymes that inhibit the formation of fat (Hexsel and Soreifmann, 2011). Caffeine has a hydrophilic property with a $\log P$ value of -0.07 , and it indicates that caffeine will be difficult to penetrate into the skin because the skin is mostly composed of lipids, so the skin becomes lipophilic. Also, the hydrophilic nature of caffeine will complicate the penetration path into subcutaneous tissue to work as anti-cellulite. So it needs a modification of caffeine form to increase its penetration into the skin (Luo and Lane, 2015).

Emulsions are a mixture of water phases with various

\section{${ }^{*}$ Corresponding Author}

Raditya Iswandana, Laboratory of Pharmaceutical Formulation and Development, Faculty of Pharmacy, Universitas Indonesia, Depok, 16424, Indonesia.E-mail: raditya@farmasi.ui.ac.id oils. Emulsion type consists of water in oil (w/o) and oil in water $(\mathrm{o} / \mathrm{w})$. The type of water in oil is used when the drug can be soluble in water and emulsion formula have an oil base or for the specific therapeutic reason (Aulton, 2002). In the previous studies, w/o caffeine emulsions have good stability and can increase their penetration into the skin as they have similar characteristics to the skin membrane (Clément et al., 2000). Besides emulsions, the microemulsion is used as a comparison. The microemulsion is a system consisting of oil, water, surfactant, and co-surfactant that having a transparent or clear appearance with average droplet diameter of 6-100 nm (Remington and Allen, 2003). In the previous studies, caffeine microemulsion improved skin permeability, caffeine bioavailability in carriers, and had the best penetration results compared to caffeine emulsions (Bolzinger et al., 2008).

The effect of caffeine dosage forms like cream, gel, and ointment as anti-cellulite have been investigated and resulted in the best penetration value of caffeine possessed by gel preparation (Djajadisastra, 2014). Stick is a semisolid dosage form which began to be used in the medical world as antibiotics, local anesthesia, sunscreen, to antiviral (Allen, 2015). The preparation of 
caffeine sticks could become one of the innovations of new dosage forms or the use of other caffeine preparations as anti-cellulite. In addition to being an innovation and choices, these sticks have advantages because it does not use the hand as an applicator and its use by smearing more effectively to the direct location.

Therefore, this research was made formulations of sticks containing caffeine in the form of emulsions and microemulsion. They were made with a type of water in oil (w/o) to allow the caffeine to dissolve in the water phase and dispersed by sticks which largely composed of oil. The penetration test by the Franz diffusion cell method was performed to observe the amount of caffeine to passing through the skin membrane of caffeine stick formulations, and the results of data were compared. Besides penetration test, the physical and chemical stability of caffeine stick were also observed.

\section{MATERIALS AND METHODS}

\section{Materials}

Caffeine (CSPC, China), white beeswax (Brataco, Indonesia), carnauba wax, castor oil (Brataco, Indonesia), olive oil (DVL Analisi, Italy), liquid paraffin (Taidas, China), propylene glycol (Brataco, Indonesia), Span 80 (Croda, Singapore), Span 20, Tween 80 (KAO, Japan), butyl hydroxy toluene (Brataco, Indonesia), methylparaben (Brataco, Indonesia), and aquadest.

Animals: 8-10 weeks of Sprague-Dawley female rats with weight of 150-200 g (Institut Pertanian Bogor, Indonesia).

\section{Preparation of caffeine emulsion and microemulsion}

Table 1 showed the formula of an emulsion. Span 80 and Span 20 was used an emulsifier with HLB (Hydrophilic-Lipophylic Balance) of 5 to create water in oil emulsion type. Caffeine was dissolved into aquadest as the water phase. Then Span 80 , Span 20, and liquid paraffin were mixed as the oil phase. Both were heated separately at $70^{\circ} \mathrm{C}$, and all phase were mixed and stirred at 7,000 rpm by the homogenizer (IKA T25 digital, Malaysia) for $5 \mathrm{~min}$.

Table 1: Formula of emulsion.

\begin{tabular}{lc}
\hline Materials & Concentration (\% w/w) \\
\hline Caffeine & $100 \mathrm{mg}$ \\
Surfactant & 10 \\
Span 80 & 83.7 \\
Span 20 & 16.3 \\
Aquadest & 20 \\
Liquid paraffin & 70 \\
\hline
\end{tabular}

*amount of caffeine in stick formulation.

\section{Pseudo-ternary phase diagram}

The diagram was done by water titration method. The mixture of oil and surfactant-co-surfactant (Span 80-Tween 80 (S80-T80) : propylene glycol (PG) 4: 1) was made with a ratio of $1: 9,2: 8,3: 7,4: 6,5: 5,6: 4,7: 3,8: 2,9: 1(\% \mathrm{w} / \mathrm{w})$. The water was dripped into the mixture until a clear liquid which indicated that microemulsion was formed (Lou et al., 2012). This method was performed using a hot plate at $80^{\circ} \mathrm{C}$ with a magnetic stirrer speed of 3,500 rpm. The volume of water was recorded and then incorporated into the pseudo-ternary phase diagram by using Chemix School Version 3.60 program.

\section{Preparation of stick}

Table 2 showed the formula of the stick. White beeswax and carnauba wax were mixed and heated over the hotplate until melted completely at $80^{\circ} \mathrm{C}$ (mixture A). Oil phase materials such as castor oil and some olive oil were heated at $80^{\circ} \mathrm{C}$ above water bath (mixture B). BHT and methylparaben were dissolved into some olive oil and then mixed into the mixture B. After the mixture was completely melted, the mixture B added to the A mixture above the hotplate (mixture $\mathrm{A}+\mathrm{B}$ ). Caffeine was added to the mixture and stirred using homogenizer at $1000 \mathrm{rpm}$ on the hotplate at $80^{\circ} \mathrm{C}$ for $5 \mathrm{~min}$. The mixture poured into the mold then cooled for $30 \mathrm{~min}$.

Table 2: Formula of stick.

\begin{tabular}{lccc}
\hline Materials & $\begin{array}{c}\text { Formula 1 } \\
(\mathbf{\%} \text { w/w) }\end{array}$ & $\begin{array}{c}\text { Formula 2 } \\
(\mathbf{\%} \text { w/w) }\end{array}$ & $\begin{array}{c}\text { Formula 3 } \\
(\mathbf{\%} \text { w/w) }\end{array}$ \\
\hline Caffeine & 1 & - & - \\
Caffeine emulsion & - & $\sim 1^{* *}$ & - \\
Caffeine microemulsion & - & - & $\sim 1^{* *}$ \\
White Besswax & 10 & 10 & 10 \\
Carnauba wax & 5 & 5 & 5 \\
Castor oil & 53 & ad 53 & ad 53 \\
Olive oil & 30.85 & 30.85 & 30.85 \\
BHT & 0.05 & 0.05 & 0.05 \\
Methyl paraben & 0.1 & 0.1 & 0.1 \\
\hline
\end{tabular}

** the amount of caffeine in Formula 2 and Formula 3 is equivalent to the amount of caffeine in Formula 1.

\section{Evaluation of emulsion and microemulsion}

\section{Physical appearance}

The physical appearance such as shape, color, and aroma of emulsion and microemulsion preparation was observed. The result of a good physical appearance evaluation a good shape, color, and aroma and no changed to the preparation during the evaluation process (Fernandes et al., 2013).

\section{Globules size measurement}

Globules size test was performed on emulsion and microemulsion by using particle size analyzer (Beckman Coulter, USA) with dynamic light scattering principle.

\section{Evaluation of stick}

\section{Physical appearance}

The physical appearance such as shape, color, and aroma of sticks preparation was observed. The result of a good physical appearance evaluation has a good shape, color, and aroma and no changed to the preparation during the evaluation process (Fernandes et al., 2013). 


\section{Homogeneity test}

Physical homogeneity was observed by applying the dosage on the glass of the object to saw the homogeneous arrangement and whether the rough fragments were visible (Fernandes et al., 2010). Chemical homogeneity was done by dividing the stick into three parts, the top, the middle, and the bottom then measured the amount of caffeine. The measurement of caffeine assay from each part was done by extracting the caffeine from the stick.

\section{Melting point}

The test was performed by using the differential scanning calorimeter (DSC8000, USA). The melting temperature of the stick was seen in the temperature range $0-100^{\circ} \mathrm{C}$. The temperature at which the stick started to melt was called a melting temperature. A good stick can melt at body temperature so it can allow the penetration of the drug into the body.

\section{Hardness test}

The test was performed used a needle penetrometer where the stick was placed in a horizontal position. The needle placed in the center of the stick surface. The device was operated, and the needle started to move into the stick until it stops automatically. Stick hardness was measured by $\mathrm{mm} /(\mathrm{g} / \mathrm{sec})$ unit.

\section{Physical and chemical stability of stick}

The stability of stick was observed for two main components, organoleptic (form, color, and aroma) and the content of caffeine in the stick during storage at three different temperatures. Storage was carried out at high temperatures $\left(40 \pm 2^{\circ} \mathrm{C}\right)$, room temperature $\left(29 \pm 2^{\circ} \mathrm{C}\right)$, and low temperature $\left(4 \pm 2^{\circ} \mathrm{C}\right)$ for eight weeks. Organoleptic changes and measurements of caffeine content were observed every two weeks.

The measurement of caffeine content was done by extracting caffeine from sticks using a heating method with water. Stick that contained $100 \mathrm{mg}$ of caffeine was placed into the Erlenmeyer flask with $20 \mathrm{ml}$ of water then heated over a water bath at $70^{\circ} \mathrm{C}$ for $15 \mathrm{~min}$. Sticks will be melted and formed two fluid layers inside the flask. The water layer was at the bottom and the oil layer at the top. Erlenmeyer flask was shaken gently to allow caffeine to dissolve in the water layer and until the top of the oil layer hardens. The water layer was removed from the Erlenmeyer flask into the measuring flask. This step was done triplicate until the water in the measuring flask was $60 \mathrm{ml}$. Then, the volume of measuring flask was filled to $100 \mathrm{ml}$ with water and shaken until homogeneous. The absorption of the solution was analyzed by UV-Vis spectrophotometer (UV-1800 Shimadzu, Japan) at the maximum wavelength of caffeine. This experiment was done triplicate.

\section{Penetration test using franz diffusion cell}

Before the penetration test, female Sprague-Dawley rats aged 8-10 weeks with a weight \pm 150 gram was prepared as a membrane. The abdomen part was shaved carefully and cut into a circle with a diameter of $\pm 2 \mathrm{~cm}$. The penetration instrument was prepared by filling the receptor compartment with $14 \mathrm{ml}$ phosphate buffer $\mathrm{pH} 7.4$ and stirred using magnetic stirrer at $300 \mathrm{rpm}$. The membrane was placed between the donor and the receptor compartment then hydrate for 30 minutes. About 1 gram stick was placed in the donor compartment. The temperature of the receptor compartment was maintained by a water jacket at $37 \pm 0.5^{\circ} \mathrm{C}$ using a thermostat. Samples was taken as much as $0.5 \mathrm{ml}$ at $10,20,30$, $45,60,90,120,180,240,300,360,420,480,540,600,660$ and $720 \mathrm{~min}(12 \mathrm{~h})$. Each time the sample was taken, $0.5 \mathrm{ml}$ receptor solution was added to replace sample (Ramadon et al., 2017). Samples were diluted with phosphate buffer $\mathrm{pH} 7.4$ in a $5 \mathrm{ml}$ measuring flask and analyzed by using UV-Vis spectrophotometer at a maximum wavelength to determine its uptake. This experiment was carried out three times for each formula. Penetration test was done after received the ethical approval from Medical Research Ethics Committee of Faculty of Medicine UI with registration No. 200/UN2.F1/Etik/2017 related to the experimental animal, Sprague-Dawley female rats.

\section{RESULTS AND DISCUSSION}

\section{Preparation of emulsion}

Based on Bancroft's Rule, the emulsion type was determined by the emulsifier, and it must be soluble in the continuous phase or outer phase. Low emulsifier HLB values, generally had good solubility in oil and formed water in oil emulsion (Swarbrick, 2007). The use of a combination of Span 80 and Span 20 as emulsifiers improved the stability of emulsions with water in oil type (Morales et al., 2009). Caffeine has a water solubility of 16 $\mathrm{mg} / \mathrm{ml}$ at room temperature, $200 \mathrm{mg} / \mathrm{ml}$ at $80^{\circ} \mathrm{C}$ and $666 \mathrm{mg} / \mathrm{ml}$ at $100^{\circ} \mathrm{C}$ or boiling water (Moffat, 2004). So, caffeine was dissolved in water at $80^{\circ} \mathrm{C}$ to avoid crystallization. The water phase and the oil phase were mixed then stirred immediately using Ultra-Turrax homogenizer at 7,000 rpm. High speed decreased the viscosity and reduced the potential for phase separation.

\section{Preparation of microemulsion}

\section{Pseudo-ternary phase diagram}

Aquadest as water phase was dripped into an oil mixture and surfactant-co-surfactant with a ratio of 1:9 to 9:1. This method was performed using the hot plate at $80^{\circ} \mathrm{C}$ with speed $3,500 \mathrm{rpm}$ of a magnetic stirrer. The $80^{\circ} \mathrm{C}$ temperature was chosen because liquid paraffin has long iso-alkane chains that difficult to formed microemulsion at low temperatures. High temperature decreased the interface tension and droplet diameter (Barel et al., 2014). Propylene glycol as a co-surfactant has short or medium chain alcoholic (C3-C8) which it can diffuse rapidly between the oil and water phases so that the water and oil interface tension decreased (Lawrence and Rees, 2000). 


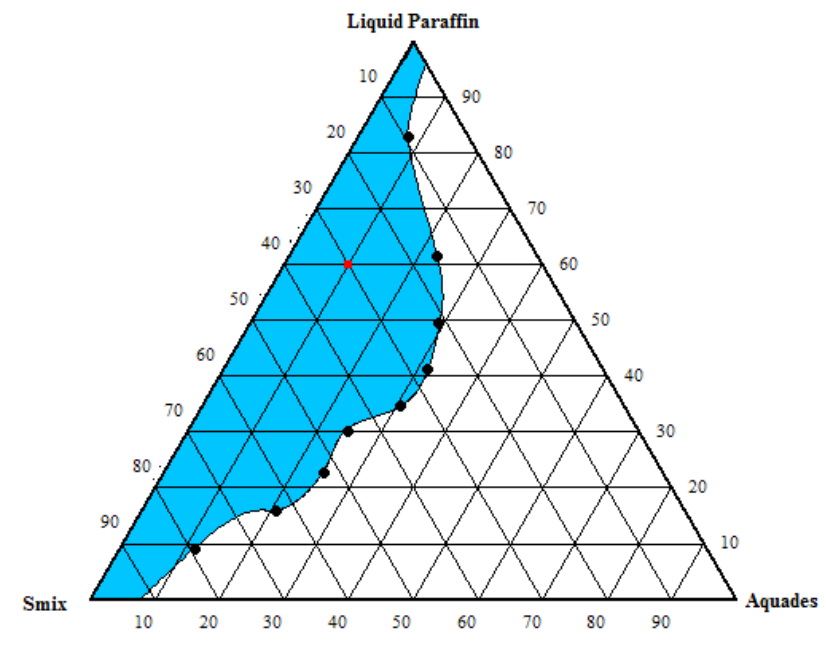

Fig. 1: The result of pseudo-ternary phase diagram.

The diagram in Figure 1 demonstrated that the more amount of liquid paraffin and the less amount of surfactant-co-surfactant resulted in the less amount of water to be added. Based on the previous study, the higher amount of water tended to lead to the formation of nanoemulsion which had a cloudy or not clear organoleptic and thermodynamically unstable (Barel et al., 2014). The blue area on the diagram showed the region that produced a microemulsion and the red dot was the chosen formula to form the microemulsion.

\section{Microemulsion formulation}

Based on Figure 1, the more water was added, the cloudier formula result. Cloudy indicated that microemulsion could not be formed because microemulsion has clear or transparent organoleptic (Guang and Ping, 2010). The microemulsion formula was a red dot in the diagram with the water concentration was $10 \%$, and the oil concentration was $60 \%$. It was based on the solubility of caffeine in water. The experimental showed $10 \%$ of water could dissolve caffeine well in hot temperatures $\left(80^{\circ} \mathrm{C}\right)$. Caffeine dissolved well in hot temperatures, but when the amount of water used was low, caffeine immediately formed crystals as the temperature drops and interferes with the formation of microemulsions.

\section{Preparation of stick}

The sticks were made into 3 Formulae based on the difference of active substances. Formula 1 (control stick) used the active substance of caffeine in its basic form (powder). The amount of caffeine powder was $1 \%$ of the total formulation or $100 \mathrm{mg}$ in $10 \mathrm{~g}$ of the stick. Formula 2 (emulsion stick), the active ingredient used was caffeine emulsion. While in Formula 3 (microemulsion stick), the active substance used was caffeine microemulsion. Emulsions and microemulsion were added into the sticks as much as $50 \%$ of the total formulation or $5 \mathrm{~g}$ in $10 \mathrm{~g}$ of sticks. In $5 \mathrm{~g}$ of emulsion and microemulsion, there was $100 \mathrm{mg}$ caffeine according to the amount of caffeine used in control stick.

Caffeine has a hydrophilic nature that caused it difficult to dissolve in the hydrophobic components. This case made caffeine not homogeneously distributed in control stick and tend to settle on the bottom surface of the stick when molding process. Emulsion and microemulsion have water in oil type with an outer oil phase were liquid paraffin. The used of caffeine emulsions and microemulsions could eliminate the homogeneity problem that occurred in the control stick so that in emulsion stick and microemulsion stick, better sticks were produced with the spread of homogeneous active substances.

\section{Evaluation of emulsion and microemulsion}

\section{Physical appearance}

Caffeine emulsions and microemulsion were liquids. The emulsion had a milky white color with a low viscosity. The microemulsion had a translucent color with a higher viscosity level than emulsion. It can be caused by the amount of water contained in the emulsion and microemulsion formulations. In the emulsion preparation, water was used more than $10 \%$ compared to microemulsion, so the emulsion had a low viscosity or tended to be more aqueous than microemulsion.

\section{Globules size measurement}

Measurements used a parameter of the diameter by volume (Dv). The size distribution of globules measured by Dv results was more specific because the Dv value was related to the actual diameter size. Measurement of Dmean or average volume diameter showed globule size of microemulsion was $10.1 \mathrm{~nm}$, and globule size of the emulsion was $68.4 \mathrm{~nm}$. The Dmean value was chosen to be the actual size of emulsion and microemulsion globule size because Dmean was the average value of the $100 \%$ globule measurement in the sample.

\section{Evaluation of stick}

\section{Physical appearance}

The three sticks had a cylindrical shape with a diameter of $2 \mathrm{~cm}$ and had a distinctive oil scent. There was a color difference between them. Control sticks were yellow, emulsion sticks tended to be white, and the microemulsion sticks had yellowish-white color. It happened because of the active substances contained in each formula. Stick controls contain caffeine powder, so the sticks formed a bright yellow color according to the original color of the stick constituent components. Emulsion sticks contained milky white emulsions, and microemulsion sticks contained a translucent microemulsion so that the color of the sticks formed adjusts to the color of the active substances.

\section{Homogeneity test}

The result of physical homogeneity on three sticks showed they have good homogeneity. It can be seen in the absence of rough fragments. Chemical homogeneity measurements showed in Table 3 that caffeine content was not evenly distributed throughout the portion of the stick. Most caffeine levels were 
found on the bottom of the stick. This occurred due to the deposition of the active substance during the molding process. The time or duration of the hardened sticks in the molding process can be a factor causing the precipitation of the active substance.

Table 3: The results of caffeine content from 3 parts of stick $(n=3)$.

\begin{tabular}{lccc}
\hline & \multicolumn{3}{c}{ Caffeine Content (\%) } \\
\cline { 2 - 4 } & Top & Middle & Bottom \\
\hline Control Stick & $65.17 \pm 0.68$ & $66.92 \pm 1.45$ & $115.12 \pm 3.32$ \\
Emulsion Stick & $84.64 \pm 2.37$ & $96.50 \pm 1.18$ & $124.22 \pm 2.13$ \\
Microemulsion Stick & $55.34 \pm 0.65$ & $74.51 \pm 1.37$ & $145.28 \pm 4.54$ \\
\hline
\end{tabular}

\section{Melting temperature measurement}

The thermogram results of the three sticks showed the onset sign, peak sign, and ending sign. The onset sign showed the temperature when the sticks started to melt, and the ending sign showed the temperature when the stick melted perfectly. The control stick melted precisely at $47.04^{\circ} \mathrm{C}$, emulsion sticks at $36.02^{\circ} \mathrm{C}$, and microemulsion sticks at $36.26^{\circ} \mathrm{C}$. The low melting temperature of the emulsion stick caused by the components of the sticks. The content of active substances caffeine emulsion in the form of aqueous liquid reduced the hardness of stick that affected to easy smelting. Microemulsion sticks had a melting temperature which almost like emulsion sticks. The melting temperature of the emulsion stick and the microemulsion sticks indicated that both sticks were easy to apply because they melted at human body temperature $\left(37^{\circ} \mathrm{C}\right)$.

\section{Hardness test}

Measurements were performed at weeks 0 and week eight at room temperature $\left(29 \pm 2{ }^{\circ} \mathrm{C}\right)$. The smaller value it took, the higher level of hardness. The hardness value of stick depends on the depth $(\mathrm{mm})$ of the needle that penetrated the stick $(\mathrm{g})$ per unit time (sec). Hard sticks result in a small value because of the needle difficult to penetrate the stick. The control stick had the smallest value so it has the highest level of hardness and the emulsion stick has the highest value, so it became the softest stick.

The difference of hardness value showed in Table 4. It caused by the active substance contained in each formula. Emulsion sticks contained emulsions that had a watery texture, and it tended to form a soft stick. A soft stick made the penetrometer needle penetrate the stick easily, so the result of hardness value was large. The control stick had the highest level of hardness because the active ingredient did not affect the mass of the stick. The low value of hardness control stick was caused because of the penetrometer needle difficult to penetrate the stick. From all sticks, the control sticks have the highest hardness followed by microemulsion sticks and emulsion sticks.

Table 4: The hardness value of stick $(n=3)$.

\begin{tabular}{lccc}
\hline \multirow{2}{*}{ Week } & \multicolumn{3}{c}{ Hardness $(\mathrm{mm} /(\mathrm{gram} /$ second) } \\
\cline { 2 - 4 } & Control Stick & Emulsion Stick & Microemulsion Stick \\
\hline 0 & $8.18 \pm 1.04$ & $13.65 \pm 0.92$ & $12.66 \pm 0.02$ \\
8 & $10.55 \pm 0.45$ & $14.81 \pm 0.10$ & $14.08 \pm 0.83$ \\
\hline
\end{tabular}

\section{Physical and chemical stability of stick}

The results of physical stability of sticks at room temperature $\left(29 \pm 2^{\circ} \mathrm{C}\right)$ and cold temperatures $\left(4 \pm 2^{\circ} \mathrm{C}\right)$ showed stable due to no changed of shape, color, and scent. Sticks at hot temperatures $\left(40 \pm 2^{\circ} \mathrm{C}\right)$ showed slight changes to shape, but not with color and scent. The sticks became slightly soft or oily. This happened because the stick cannot stand in the hot temperature and tends to melt even though the temperature of $40 \pm 2^{\circ} \mathrm{C}$ was not enough to melt the stick perfectly.
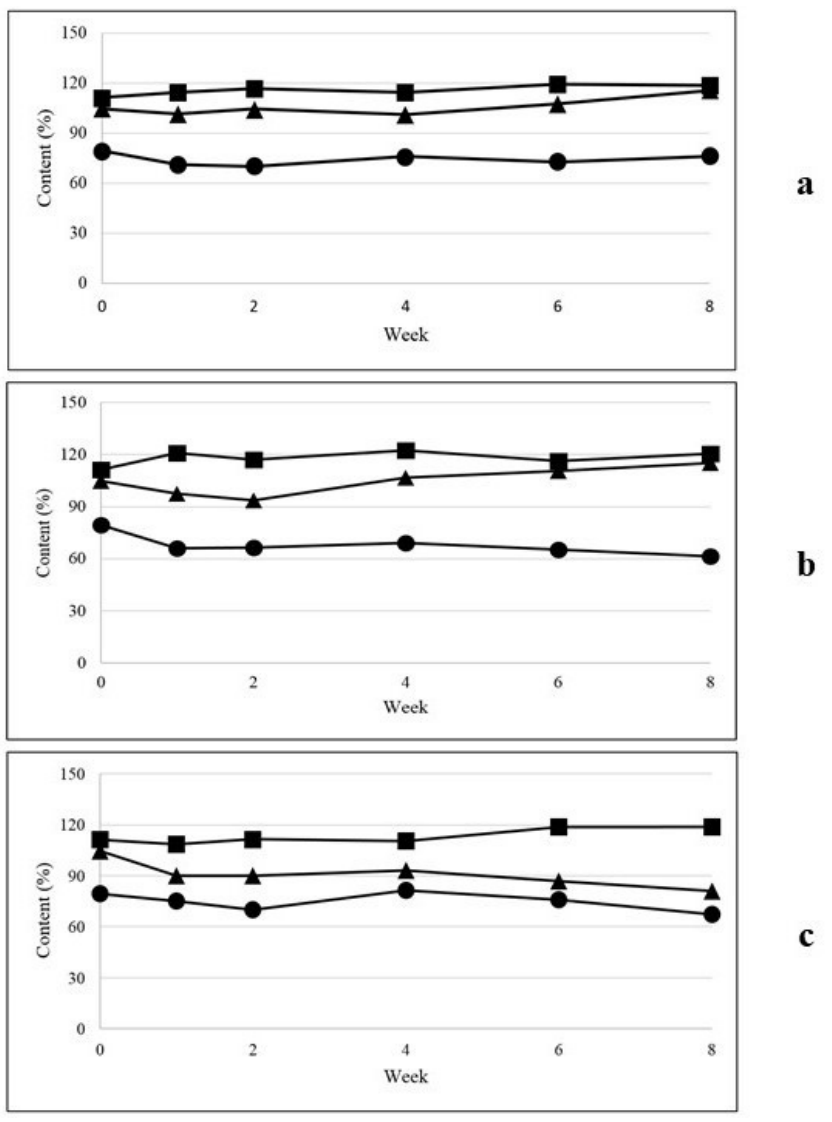

Fig. 2: Chemical stability of the three sticks for eight weeks storage in: (a) room temperature, (b) cold temperature, (c) hot temperature.

The chemical stability was performed at week 0 , week 1 , week 2 , week 4 , week 6 , and week eight by measure the caffeine content. The caffeine content of the sticks was done by extracting caffeine from the sticks by heating. Based on the graphs in Figure 2, the caffeine content in three sticks at all temperatures was stable. At week 0, the caffeine content in the control sticks was $79.34 \pm 3.86 \%$, in the emulsion sticks was $111.18 \pm 9.38 \%$, and in the microemulsion sticks was $104.57 \pm 3.86 \%$. Emulsion sticks had the highest levels of caffeine because of the content of $20 \%$ water able to dissolve the caffeine well. The difference of the amount of water produced caffeine levels in microemulsion stick lower than emulsion sticks. Also, the melting temperature of the emulsion stick was lower than microemulsion stick so the sticks are easier to melt at the temperature in the extraction process. The 
control stick had the smallest levels of caffeine caused by the caffeine in the control stick stuck in the base during the extraction process. The hydrophilic character of caffeine could not be dispersed evenly within the hydrophobic control sticks. The condition and storage time did not significantly affect caffeine levels in the dosage form. The graphs showed caffeine levels in three temperatures tended to be stable. A slight increase and decrease can be attributed to a lacked caution during the extraction process every week.

\section{Penetration test using franz diffusion cell}

The cumulative amount of caffeine that can be penetrated for $12 \mathrm{~h}$ from the control stick, emulsion stick, and microemulsion stick were $306.42 \pm 34.92 \mu \mathrm{g} / \mathrm{cm}^{2}, 927.75 \pm 57.38 \mu \mathrm{g} /$ $\mathrm{cm}^{2}$, and $2408.68 \pm 81.65 \mu \mathrm{g} / \mathrm{cm}^{2}$, respectively. The profile of caffeine penetration of the sticks can be seen in Figure 3. Based on the amount of caffeine concentrated, the percentage of caffeine from the control stick, emulsion stick, and microemulsion stick were $5.90 \pm 0.67 \%, 12.76 \pm 0.78 \%, 35.23 \pm 1.19 \%$, respectively.

Based on the graph in Figure 3, the penetration profile of the three sticks has a fairly obvious difference. The microemulsion sticks penetrated caffeine from the first point of sampling, which was the minute-10 and a constant increased until minute- 720 . Increases also occurred in emulsion sticks, but in the minute-10 until the minute-420, the emulsion stick penetration profile was closed to the control stick profile. It can occur for two reasons. First, the sample of emulsion sticks in the donor compartment was non-homogeneous so that in the early minutes, the concentration of caffeine came from the part of stick containing small amount of caffeine than in the minute- 420 , concentration of caffeine increased as the part of the big amount of caffeine in the stick began to penetrate. Secondly, the melting process of emulsion sticks in these minutes were not maximal. Caffeine was difficult to penetrate the receptor compartment. The control stick has a constant penetration profile. This happened because the control stick did not melt properly at the experiment temperature.
Based on the cumulative amount of concentrated caffeine, the microemulsion sticks had the largest cumulative amount compared to the control sticks and emulsion sticks. This occurred because the microemulsion stick contained the active ingredient of caffeine microemulsion, where the water phase in microemulsion can dissolve caffeine then coated by the outer phase of the oil which formed the particles size into small and making it easier for caffeine to enter the skin. Also, the oil base of the sticks preparation was absorbed through the intracellular transepidermal route (Dragicevic and Maibach, 2016). The control stick had the smallest amount of cumulative due caffeine was not homogeneously dispersed, so it tends to settle beneath the surface of the stick. Also, the melting temperature of the control sticks was quite high, where the temperature was not the normal temperature of the human body, so the control sticks did not melt perfectly at the experiment temperature that simulates the human body. That became the reason why caffeine in the control sticks was difficult to penetrate. Emulsion sticks had constituent components like microemulsion sticks. However, caffeine emulsions had larger particle sizes than caffeine microemulsion. The size of the particle made the caffeine did not penetrate optimally so that the cumulative amount of caffeine can be said to be quite low compared to the microemulsion sticks.

The caffeine flux in the preparation was a gradient value obtained from the linear regression equation on the cumulative graph starting from 360 to $720 \mathrm{~min}$. Based on Figure 4, the flux values of control sticks, emulsion sticks, and microemulsion sticks were $0.2921 \mu \mathrm{g} / \mathrm{cm}^{2}$.hour ${ }^{-1}, 1.7331 \mu \mathrm{g} / \mathrm{cm}^{2}$.hour ${ }^{-1}$, and $2.8237 \mu \mathrm{g} /$ $\mathrm{cm}^{2}$.hour ${ }^{-1}$, respectively. The diffused substance from the donor compartment to the receptor compartment occurred by passive diffusion in Fick's law. The essential condition of a diffusion process is steady state. The first Fick's law provides the flux or speed of diffusion through the unit area in the steady state. The second Fick law stated a change in the diffusion concentration over time at a certain distance such as the flow of non-steady conditions (Sinko, 2012).

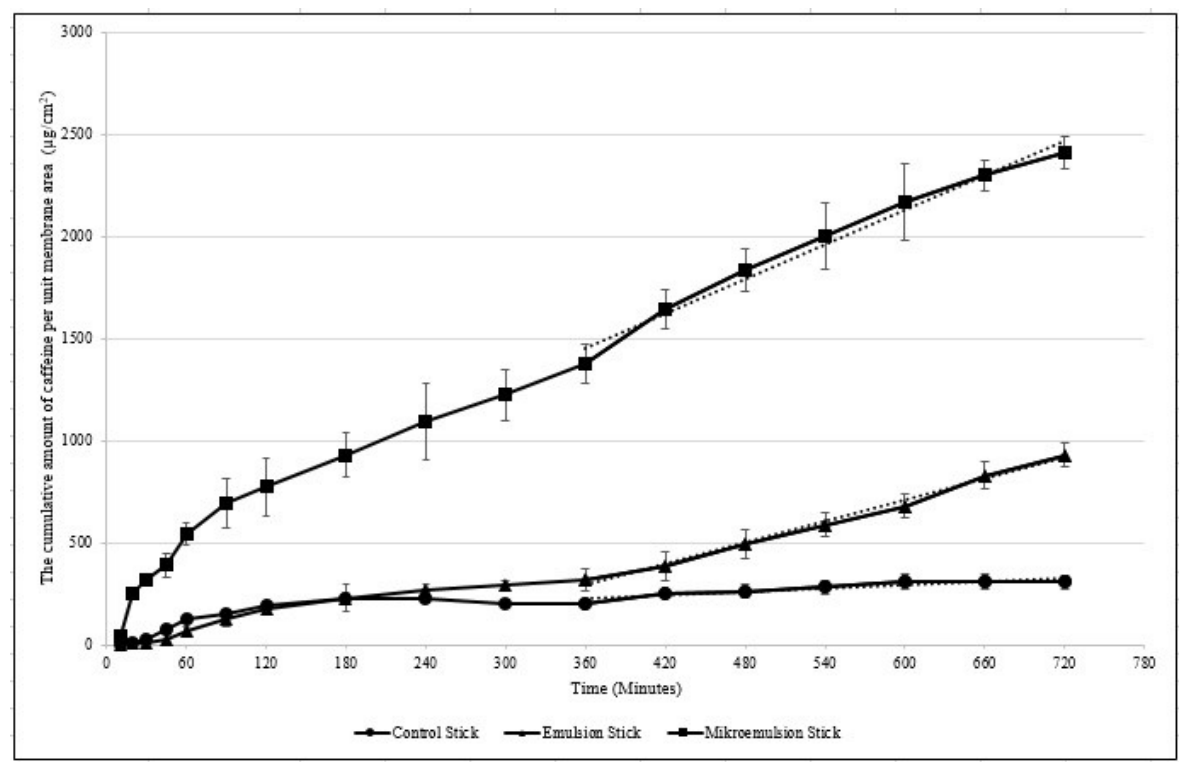

Fig. 3: Cumulative amount of caffeine per unit membrane area of control sticks, emulsion sticks, and microemulsion sticks. 


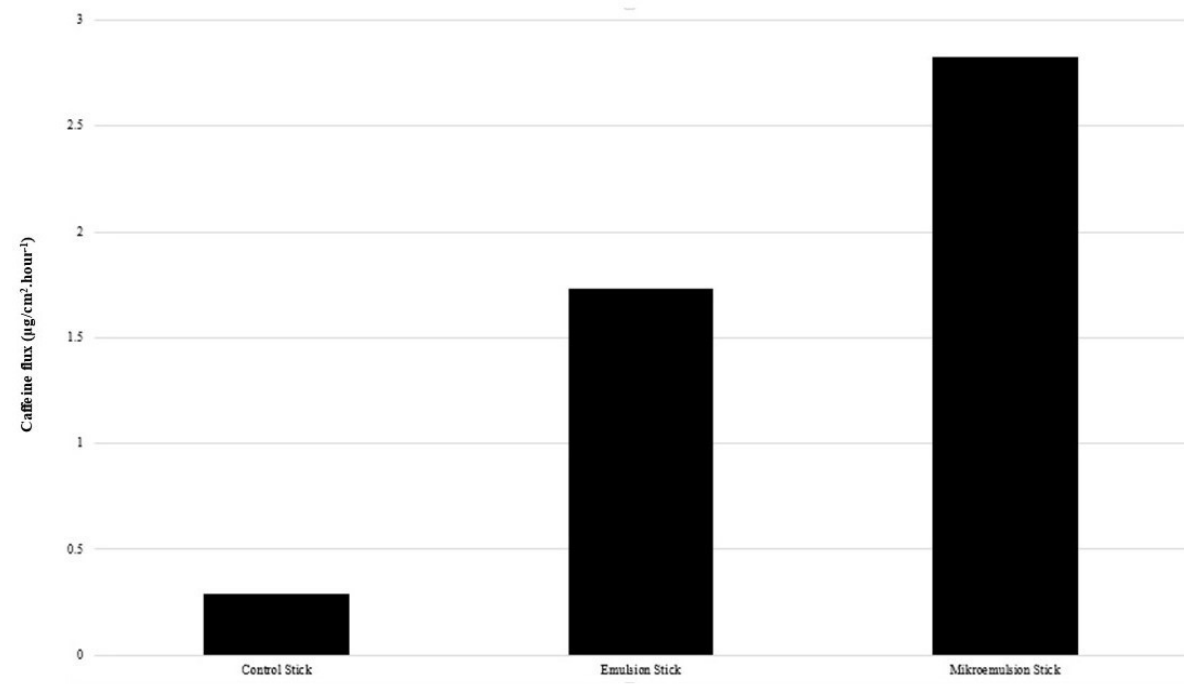

Fig. 4: The caffeine flux graph of control stick, emulsion stick, and microemulsion stick.

\section{CONCLUSION}

Based on the result of a penetration test, it concluded that microemulsion sticks gave the highest penetration result with the cumulative amount of caffeine was $2408.68 \pm 81.65 \mu \mathrm{g} / \mathrm{cm}^{2}$ compared to control stick was $306.42 \pm 34.92 \mu \mathrm{g} / \mathrm{cm}^{2}$ and emulsion stick was $927.75 \pm 57.38 \mu \mathrm{g} / \mathrm{cm}^{2}$. Furthermore, it concluded that the control stick, emulsion sticks, and microemulsion sticks were relatively stable.

\section{CONFLICT OF INTEREST}

The authors have no conflict of interest to declare.

\section{REFERENCES} 2015; 5(3).

Allen L. Compounding medication sticks. Secundum Artem

Aulton M. Pharmaceutics: The Science of dosage form design (2nd ed). London: Churchill Livingstone; 2002.

Barel A, Paye M, Maibach H. Handbook of cosmetic science and technology, Fourth Edition. London: CRC Press; 2014.

Bolzinger M, Briançon S, Pelletier J, Fessi H, Chevalier Y. Percutaneous release of caffeine from microemulsion, emulsion, and gel dosage forms. European Journal of Pharmaceutics and Biopharmaceutics 2008;68(2),446-51.

Clément P, Laugel C, Marty J. In vitro release of caffeine from concentrated $\mathrm{W} / \mathrm{O}$ emulsions: effect of formulation parameters. International Journal of Pharmaceutics 2000;207(1-2):7-20.

Djajadisastra J. Percutane Transport profile of caffeine and aminophylline as anti-cellulite and the influences of other substances on in vitro penetration. International Journal of Pharmacy and Pharmaceutical Sciences 2014;6(5):532-38.

Dragicevic N, Maibach H. Percutaneous penetration enhancers chemical methods in penetration enhancement. New York: Springer; 2016.

Fernandes A, Dario M, Pinto C, Kaneko T, Baby A, Velasco, M. Stability evaluation of organic lip balm. Brazilian Journal of Pharmaceuti- cal Sciences 2013;49(2):293-9.

Guang WL, Ping G. Emulsions and microemulsions for topical and transdermal drug delivery. United States of America: Elsevier; 2010.

Hexsel D, Soreifmann M. Cosmeceuticals for cellullite. Seminars in Cutaneous Medicine and Surgery 2011;167-70.

Lawrence M, Rees G. Microemulsion-based media as novel drug delivery systems. Advanced Drug Delivery Reviews 2000;45(1):89-121.

Lou H, Qiu N, Crill C, Helms R, Almoazen H. Development of W/O microemulsion for transdermal delivery of iodide ions. AAPS Pharmscitech 2012;14(1):168-76.

Luo L, Lane M. Topical and transdermal delivery of caffeine. International Journal of Pharmaceutics 2015; 490(1-2): 155-64.

Moffat A. Clarke's analysis of drugs and poisons ( $3^{\text {rd }}$ ed.). London: Pharmaceutical Press; 2004.

Morales C, Riebel U, Guzman M, Guerra M. W/O Emulsion: formulation, characterization, and destabilization ( $1^{\text {st }}$ ed). Venezuela: Brandenburgische Technische Universtat Cottbus; 2009.

Ramadon D, Wirarti GA, Anwar E. Novel transdermal ethosomal gel containing green tea (Camellia sinensis L. Kuntze) leaves extract: formulation and in vitro penetration study. Journal of Young Pharmacists 2017;9(3):336-40. Press; 2003.

Remington J, Allen L. Remington. London: Pharmaceutical

Sinko, PJ. Martin's physical pharmacy and pharmaceutical sciences $\left(6^{\text {th }}\right.$ edition). Philadelphia: Lippincott Williams \& Wilkins; 2012.

Swarbrick J. Encyclopedia of pharmaceutical technology $\left(1^{\text {st }}\right.$ ed.). New York: Informa Healthcare; 2007:1548-64.

\section{How to cite this article:}

Iswandana R, Chalista W, Sitepu ES. Formulation and Penetration Enhancement Activity of Sticks Containing Caffeine. J App Pharm Sci, 2018; 8 (01): 043-049. 